\title{
META-METODE APOLOGETIKA ATAU, APOLOGETIKA (SEBAGAI) META-METODE
}

\author{
Kevin Juwono \\ Sekolah Tinggi Alkitab Tiranus, Bandung \\ Jl. Cihanjuang Km. 5,2, Cihanjuang, Parongpong, Bandung Barat \\ kevinjuwonowong@gmail.com
}

\begin{abstract}
S: Apologetics is often identified with public opinion as merely a matter of method, practicality and certain rational systems to answer questions about faith. The meta-method of apologetics wants to shift that opinion considering the nature of apologetics as a "space" for pneuma, which revolves through dunamis and imaginarium. Thus, apologetics is rethought as a discipline, which is open to pneumatikos dynamics, not coopted into one monocultural and instrumental rationality, and moves flexibly in the face of multicontextual reality.
\end{abstract}

Keywords: apologetics, meta-method, pneuma, point of contact, dunamis, imaginarium, subject.

\begin{abstract}
ABSTRAK: Apologetika kerap diidentikkan dengan pendapat umum sebagai sematamata soal metode, kepraktisan dan sistem rasional tertentu untuk menjawab pertanyaan tentang iman. Meta-metode Apologetika hendak menggeser pendapat itu dengan menimbang hakikat Apologetika sebagai "ruang" bagi pneuma, yang bergulir melalui dunamis dan imaginarium. Dengan demikian, Apologetika ditimbang kembali sebagai disiplin ilmu, yang terbuka pada dinamika pneumatikos, tidak terkooptasi pada satu rasionalitas monokultural dan instrumental, serta bergerak luwes di hadapan realitas multikontekstual.
\end{abstract}

Kata Kunci: apologetika, meta-metode, pneuma, titik kontak, dunamis, imaginarium, subjek.

\section{PENDAHULUAN}

Metode merupakan sebuah istilah sarat paradoks. la menjadi faktor penentu progresivitas, sekaligus dekadensi serta stagnasi suatu disiplin ilmu. Spesialisasi telah menciptakan variabilitas metode mengikuti taksonomi pelbagai disiplin yang menuntut kajian berbeda pula. Penggunaan metode secara efisien menjamin penelitian berjalan pada jalurnya. Pengabaian metode merisikokan penelitian berlangsung arbitrer. Pada sisi lain, pemakaian metode ad infinitum, atau metode sebagai autoteleologis yang mengakibatkan seluruh kajian terdaras hanya sebagai bunga rampai metode, merupakan "kutukan metodis". Suasana keilmuan birokratisme yang melebur dengan pragmatisme dalam riset dapat mengantar pada kecendekiaan "terjun bebas", dan keilmuan "jalan di tempat". Demikianlah suatu disiplin ilmu tinggal sebagai tulang-belulang metode dan kepraktisan belaka serta menuju kepunahan.

Dalam disiplin teologi, kesimpangsiuran antara metode dan tubuh kajian tampak secara vulgar pada bidang Apologetika. Bidang ini telah dijejali dan dipejali oleh artifisialitas, sehingga mana kala lema Apologetika disebut, yang muncul adalah metode dan langkah-langkah praktis. Sekalipun tidak bisa dimungkiri terdapat dimensi "metodikopraktikal" pada Apologetika sebagai cabang 
disiplin ilmu Teologi Misi. Dengan asumsi bahwa hiruk-pikuk metode dan langkah praktis telah membawa bias-bias fundamental pada kajian Apologetika, sehingga dibutuhkan redefinisi dan rekonstruksi hakikat Apologetika, maka tulisan ini menawarkan suatu "jalan arkais nan anyar" dalam mendekati disiplin tersebut.

\section{METODOLOGI}

Artikel ini menggunakan kajian literatur, dengan memilih beberapa sumber literatur tercantum, lalu melakukan proses hermeneutis/pembacaan, termasuk analisis di dalamnya, secara kritis dan konstruktif. Sumber teks Apologetika berasal dari dua tokoh apologet, Bernard L. Ramm dan Alister McGrath. Karya ringkas Martin Heidegger menyangkut horizon filosofis digunakan sebagai analogi yang membuka perspektif baru. Sehubungan dengan gagasan pneumatologi digunakan teks teologi sistematika karya Kärkkäinen. Beberapa teks Kitab Suci yang dianggap koheren dengan topik kajian, diinterpretasikan dan disajikan. Melalui penggunaan sumber dan metode tersebut, penulis menawarkan suatu konstruksi gagasan menyangkut pendekatan meta-metode atas Apologetika. Lema meta-metode digunakan oleh penulis sesuai maksud penulis sendiri yang dijelaskan pada paparan di bawah.

\section{HASIL DAN PEMBAHASAN}

\section{Dua Analogi: Philosophia Heideggerian dan Elenchos Socratian}

Martin Heidegger, seorang filsuf Jerman abad ke-20, menyelisik fondasi mapan definisi filsafat yang telah terbangun selama berabad-abad. Dalam buku berjudul persis dengan pertanyaannya, Apa itu filsafat? Heidegger menulis bahwa para filsuf selama dua milenium mengupayakan jawaban atas pertanyaan itu. Akan tetapi, hakikat filsafat menurut Heidegger, bukan terletak pada jawaban atas apa itu, melainkan pada proses pengajuan pertanyaan itu sendiri. Pemertanyaan atas pertanyaan itulah, atau disebut sebagai a philosophizing response, yang menyingkapkan jawaban. Pertanyaan apa itu filsafat bukan soal tentang filsafat, melainkan soal ke dalam filsafat; bukan soal apa itu dalam pertanyaan, melainkan soal bagaimana kita bertanya (Heidegger, 1958, pp. 21, 35).

Pertanyaan apa itu telah menuntun para filsuf melakukan spekulasi filosofis menyangkut dasar pertama segala sesuatu: Ousia. Heraklitos menggangsir soal Logos, Plato soal Idea, dan Aristoteles soal Energeia ('aktualitas'). Segala yang diacu oleh para filsuf itu, simpul Heidegger, adalah Sein ('Being, Ada') (1958, p. 55). Pertanyaan besar itu lantas tercakup ke dalam metafisika atau ontologi. Dalam telinga orang Yunani, Logos dekat dengan legein ('itu berbicara') (1958, p. 45). Sesuai maksud Heidegger, Sein itu berbicara, atau menyingkapkan diri untuk diketahui. Sehubungan itu, term philosophia yang dicetuskan oleh Heraklitos pertama kali, tidak bermaksud mengungkap jawaban per definisi. Seorang pencinta hikmat, melampaui kategorisasi oleh kaum rasionalis, adalah person yang tergerak oleh pathos.

Dalam citarasa Heideggerian, Logos menyediakan diri melalui sophon, yang dekat dengan harmonia (1958, p. 47). To sophon itu, sebagaimana Heidegger menyulih Heraklitos, mengacu pada hen panta, "Satu (adalah) semua". Segala pengada berada di dalam Ada (seindes im Sein) (1958, pp. 48-49). Rasa keterhubungan (the sense of correspondence) pengada dengan Ada yang terungkap melalui bahasa, dialog dan dialektika itulah yang memungkinkan philosophia. Jawaban atas pertanyaan apa itu filsafat menjadi respons, atau tanggapan kepada Ada dari pengada (1958, p. 69). 
Filsafat menjadi mungkin hanya jika terjadi percakapan antara tradisi filsafat yang berlangsung dalam sejarah dan korespondensi langsung antara pengada dan Ada, sehingga jalan filosofis ialah jalan destruksi. Destruksi ala Heidegger bukan dalam arti merusak, melainkan:

... melucuti, melikuidasi, menempatkan ke samping tuntutan historis yang sebenarnya tentang sejarah filsafat. Destruksi berarti-membuka telinga kita, membebaskan diri kita dari sesuatu yang berbicara kepada kita dalam tradisi sebagai Ada dari pengada. Melalui mendengar interpelasi ini kita memperoleh korespondensi (1958, p. 71, 73).

Filsafat sebagai korespondensi kepada Ada dari pengada, dalam gagasan Heidegger, membutuhkan ketertalaan (stimmung) pengada kepada Ada, yakni philein (dalam philosophia) sebagai pathos, yang dimaknai bukan sekadar sebagai 'gairah' (passion) melainkan juga paschein: 'menderita', 'menanggung', 'menjalani' dan 'terdeterminasi oleh'. Dalam arti itu, pathos merupakan disposisi dan determinasi dalam ketertalaan, yang salah satu karakteristiknya ialah thaumazein, 'ketakjuban' (1958, pp. 83-85). Bahasa dan puisi menjadi jalan pengungkapan ketakjuban disposisi kepada Ada-nya pengada (1958, p. 93, 95). Demikian Heidegger menggugat jawaban-jawaban definitif, metodis, apalagi praktis, menyangkut philosophia, bahwa korespondensi dan ketertalaan serta keterbukaan sang filsuf yang terus berproses kepada Sein itulah yang menjadi hakikat filsafat.

Percakapan Sokrates yang terekam melalui karya tulis drama oleh Plato, tulisan filsuf sejarawan Xenophon, komedi dari dramawan Aristophanes, dan tulisan-tulisan Aristoteles, kemudian dikaji dan dikenal sebagai dialog Sokratik atau metode Sokrates atau elenchos. Dalam kamus-kamus bahasa
Inggris, elenchos telah diserap ke dalam lema bahasa Inggris, yakni elenchus. Pencarian kata kunci elenchus pada mesin pencarian Google (selaras dengan definisi dari beberapa kamus lain), menampilkan arti: "a logical refutation", yang dijelaskan sebagai "the Socratic method of eliciting truth by question and answer, especially as used to refute an argument." Elenchus telah mendapat definisi standar yang mengacu pada metode Socrates untuk menemukan kebenaran dengan mengajukan sanggahansanggahan atas argumen yang diajukan, baik melalui jawaban maupun pertanyaan.

Identifikasi elenchus sebagai metode, sama halnya Apologetika sebagai metode, merupakan suatu kekeliruan problematis. Sebuah bunga rampai berjudul Does Socrates have a Method? (2002 p. 327), mengulas beberapa keberatan atas metodisasi elenchus. Pertama, patut dicurigai anakronisme di dalamnya. Socrates yang dikonstruksi oleh para peneliti modern tidaklah melakukan metode sebagaimana kaum modernis mengasumsikannya. Kedua, elenchus merupakan sebuah kata yang tidak mengandung makna tunggal, tetapi bersifat multitafsir dan tidak pasti. Ketiga, elenchus bukanlah satu-satunya kata yang dapat mewakili semua dialog Socrates. Keempat, percakapan Socrates terlalu variatif dan arbitrer untuk dapat diringkus ke dalam satu metode logika penyanggahan.

Melalui analogi philosophia Heideggerian, didapati upaya Heidegger untuk membebaskan filsafat dari diskursus yang melulu berkutat pada definisi, sistematika dan metode-metode praktis, kepada suatu proses filosofis itu sendiri. Suatu proses yang pendefinisiannya bisa jadi belum selesai, serta pengajuan pertanyaan-pertanyaan dalam jalan destruksi itulah yang membuat filsafat (atau sang filsuf itu) terus hidup, terhubung dengan hakikat ultimanya. Sama halnya dengan Apologetika, yang tidak dapat 
dikungkung pada satu definisi dan metode final. Hakikat Apologetika ialah 'apologia', 'pertanggung jawaban', yang menghadapkan seorang apologet pada kemungkinankemungkinan dan situasi-situasi baru, bahkan bisa saja bersifat ad hoc, atau spontan. Keterhubungan sang apologet dengan Roh Kudus (sama seperti pengada dan Ada) yang dibahas pada bagian selanjutnya, juga menuntun pada arah-arah baru yang tidak terduga, dan terbuka.

Melalui analogi elenchos Sokratian, ditemukan bahwa kategorisasi percakapanpercakapan Sokrates yang direkam melalui para penutur lain sebagai metode Sokrates oleh para pakar modern, tidak mumpuni untuk mencakupi keragaman bentuk percakapan Sokrates. Elenchus hanyalah salah satu dari bentuk dialog. Dialog-dialog Sokrates tidak dapat disebut secara sederhana sebagai metode. Demikian pula Apologetika, yang sekalipun kerap disebut metode Apologetika, lema metode dan Apologetika seolah-olah tidak lagi saling berdiri sendiri namun saling bertumpang tindih, sehingga kedua kata itu tidak lagi dapat dibedakan. Sebagaimana dialog Sokrates dikerdilkan menjadi metode penyanggahan, maka bidang Apologetika rentan untuk diciutkan menjadi sekadar metode praktis untuk menjawab pertanyaan-pertanyaan menyangkut iman.

\section{Pneuma: Disrupsi Metode dan Sistem}

Dalam kajian teologi, salah satu bidang yang paling enigmatis ialah pneumatologi. Selama berabad-abad para teolog merasa gamang untuk menjadikan Roh Kudus sebagai objek kajian. Pendekatan atas Roh bukan melalui objektivikasi, karena Roh selalu luput dari kajian objektif. Teks-teks Kitab Suci sendiri memperlihatkan bahwa Roh bukanlah objek penelitian, melainkan Roh Allah yang melingkupi semua dan memanggil manusia untuk mendengarkan
Dia. Sebagaimana diungkap-kan oleh VeliMatti Kärkkäinen,

Roh bukanlah sebuah "objek" kajian manusia dalam cara yang sama, seperti, objek dalam sains fisika. Faktanya, kita dapat mengatakan bahwa Roh, alih-alih menjadi objek pengamatan kita, adalah Yang Satu yang menguji kita (2002, p. 15).

Sekalipun demikian, upaya berteologi tetap perlu dilakukan dalam kesadaran itu. Kärkkäinen (2002, p. 16) mengikuti Agustinus, mengusulkan korelasi erat antara pneumatologi dan spiritualitas, melalui tiga hal. Pertama, pendekatan atas Roh tidak mengacu pada teori murni tetapi pada realitas yang dialami. Kedua, pengalaman sendiri kurang mumpuni, melainkan perlu diuji, dan tidak dapat menggantikan posisi Roh Kudus itu sendiri. Ketiga, pengalaman orisinal seorang teolog dapat diuji melalui seluruh komunitas gerejawi yang dipimpin oleh Roh yang sama.

Apologetika, sebagai subdisiplin teologi, juga dimulai dalam kesadaran tersebut di atas. Roh Kudus, yang tidak dapat disistematisasi itu, dapat didekati melalui lingkup eksistensial, yakni pengalaman sang teolog atau apologet, yang berada di dalam lingkup ketakberhinggaan Roh Kudus itu sendiri, dan melalui pewiwekaan universalitas gerejawi. Di tengah hiruk-pikuk metode, usulanusulan praktis, dan sistematisasi bidang Apologetika, serta bertendensi kurang menimbang posisi pneuma, laporan teks Kitab Suci menunjukkan hal sebaliknya.

Pertama, 1 Petrus 3:15. Teks ini kerap diacukan sebagai teks Apologetika. Jemaat Yahudi diaspora yang mengalami penganiayaan dan penindasan oleh pemerintah Romawi dinasihati oleh Rasul Petrus untuk mempunyai sikap mawas, ketika sewaktuwaktu mereka diperhadapkan dengan sidang pengadilan. Mereka diharapkan dapat 
berapologia, atau memberi "pertanggungjawaban" di depan sidang atas keyakinan iman Kristen. Dalam posisi defensif itu, mereka diminta untuk mempertahankan iman dan menyatakan keyakinan mereka sebagai benar secara meyakinkan. Sikap bersiap sedia diawali dengan pesan untuk menguduskan Kristus. Dalam konteks 1 Petrus, lema Kristus melekat dengan kata Roh. Berselang empat ayat, masih dalam satu konteks perikop, pada 3:19 ditemukan istilah dalam Roh, mengacu pada Kristus yang memberitakan Injil. Secara eksplisit, dalam 1:11 disebutkan Roh Kristus, yang berperan memberikan kesaksian tentang karya Kristus, yang merupakan Roh Allah itu sendiri (1:12).

Kedua, Matius 10:19-20. Dalam situasi yang serupa dengan jemaat Yahudi diaspora di atas, komunitas Matius dipesankan untuk menyiapkan mental jika diperhadapkan ke muka pengadilan. Mereka diminta untuk tidak khawatir menyangkut argumentasi yang perlu dipaparkan. Menyangkut pembelaan yang harus diutarakan ketika di hadapan sidang, maka Roh Bapa yang akan mengajukan pembelaan melalui para murid. Strategi, metode dan sistem berapologetika menjadi terdisrupsi, atau terinterupsi, oleh peran Roh Kudus. Keterangan waktu "pada saat itu juga" menunjukkan ada spontanitas yang menginterupsi segala persiapan dan metode. Sekalipun ayat tersebut tidak mengacu pada pengabaian metode, tetapi menampilkan peran Roh Kudus dalam pertanggungjawaban iman kepada Yesus. Sekaligus pula mengungkapkan, Roh Kudus tidak dapat dimasukkan ke dalam suatu metode atau sistem tertentu.

Ketiga, 2 Korintus 10:3-6. Jika dua pertama mengacu pada apologia sebagai pembelaan defensif, atau pemberian jawab atas situasi yang menuntut itu, maka teks berikut mengacu pada Apologetika dalam tekstur afirmasi positif. Bernard L. Ramm menyebut, penyebaran Kristenitas di wilayah kekaisaran Romawi, telah menyulut resistansi para filsuf dan kaum intelektual. Mereka menuduh Kristenitas sebagai religiositas yang absurd. Lalu para apologet Kristen bermunculan pada awal abad kedua, mulai dari Aristides, Yustinus Martir, Tatianus, Athenagoras, Theophilus, Minusius Feliks dan Tertulianus (Ramm, 1975, p. 14). Rasul Paulus menuliskan semacam fungsi Apologetika di situ, yakni "mematahkan setiap siasat orang", atau logismos kathaireó: mematahkan atau mencampakkan logika, argumen, pendapat, atau pemikiran yang "menentang pengenalan akan Allah" (10:5). Sama seperti dua teks pertama, teks ketiga ini juga mengemukakan keterlibatan Roh Allah, yang disebut sebagai kuasa Allah yang memperlengkapi tugas Apologetika (10:4). Alih-alih sekadar sanggahan kritis, Apologetika dalam bentuk afirmasi positif yang disertai oleh kuasa Roh Allah, mempunyai daya untuk meruntuhkan, atau mendisrupsi sistem dan metode pemikiran yang tertutup pada penyingkapan ilahi (revelation) (Ramm, 1975, p. 23).

Berdasarkan tiga teks di atas, peran Roh Allah sangat signifikan. Berbanding terbalik dengan kajian-kajian Apologetika yang sebagian absen dalam memikirkan posisi pneuma atasnya. Peran Roh Allah yang ditampilkan melalui tiga teks menunjukkan, Roh itu sendiri tidak dapat dihisabkan ke dalam sistem dan metode Apologetika. Selain itu, peran Roh bagi "pihak luar" yang perlu ditanggapi secara apologetis, ternyata juga mendisrupsi sistem dan metode pemikiran tertutup yang menyanggah atau menentang secara kritis pewahyuan teologis. Dengan demikian, Roh tidak dapat diinjeksikan ke dalam atau ditangkis ke luar begitu saja secara hakiki oleh, metode dan sistem berpikir tertentu secara sistematis dan praktis begitu saja, baik dari pihak apologet maupun pihak kritikus. Dalam arti itu pula, Roh merupakan 
suatu enigma yang mengindikasikan, Apologetika bukan sekadar metode, kepraktisan dan sistem belaka. Oleh sebab itu, Apologetika perlu dipahami sebagai semacam "ruang" yang (tidak) cukup luas untuk menampung Dia yang tiada jua tertampung oleh suatu ruang, yakni Roh, yang akan diuraikan lebih lanjut.

\section{Meta-metode Apologetika}

Keutamaan pneuma dalam ranah Apologetika menuntut bidang ini untuk didekati lebih dari sekadar seperangkat metode dan hal-ihwal praktis, bahkan melampaui sistem tertentu dalam arti tertentu. Bagaimanakah Apologetika dapat berlangsung sebagai suatu disiplin ilmu sekaligus melampaui sekadar metode dan kepraktisan, serta memberikan ruang seluas-luasnya bagi keutamaan Roh Allah, atau Allah yang adalah Roh? Dalam hal ini penulis mengusulkan suatu metametode Apologetika atau, Apologetika sebagai meta-metode. Beberapa hal dapat dijelaskan menyangkut istilah "meta-metode", pertama, suatu $\mathrm{X}$ tentang $\mathrm{X}$. Meta-metode dalam arti ini ialah suatu metode tentang metode. Metode tentang metode bukanlah metode yang sama dengan metode yang dimetodekan. Melainkan, suatu jalan yang niscaya supaya metode dapat berjalan. Maka, kedua, meta-metode juga berarti, suatu $\mathrm{X}$ yang melampaui $X$. Metode yang menunjuk pada metode itu sekaligus pula melampaui metode yang ditunjuknya. Metode yang merujuk langkah-langkah metodis itu menjadi semacam prakondisi metode. la melampaui metode namun perlu ada supaya metode dapat dilakukan. Ketiga, suatu $X$ yang bukan $X$. Meta-metode bukanlah suatu metode, sekalipun kata metode tercantum pada lema itu. Secara etimologis, meta-metode adalah sebuah "pemborosan kata" untuk menegaskan negasinya sebagai suatu metode. Meta-metode terdiri dari meta + meta + hodos. Meta yang pertama bukanlah meto- de, karena ia tidak dikenai oleh hodos (meta + hodos $=$ methodos). Jika meta diartikan 'sesudah', maka meta-metode ialah 'sesudah-metode'. Sekalipun ke-sesudah-an yang dimaksud penulis bukanlah dalam arti kronologis, melainkan dalam arti ke-berjarak-an dengan metode, sekaligus menjadi semacam "ruang" agar metode dapat didudukkan.

Bernard L. Ramm, dalam karya klasik, The God who Makes a Difference: A Christian Appeal to Reason (1972), merangkum garis besar sistem Apologetika Kristen secara siklis, yang saya skemakan sebagai berikut.

Gambar 1. Garis Besar Sistem Apologetika Kristen ala Bernard L. Ramm

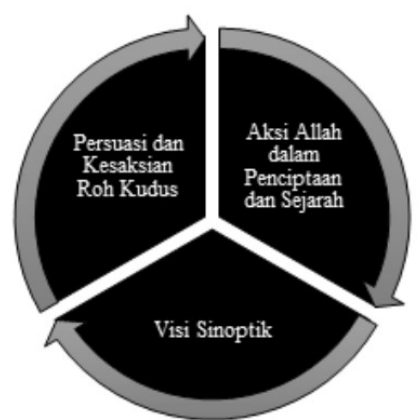

Apoivycuna rvioieı আicıupakan apologia yang mengacu pada iman Kristen yang dapat diverifikasi dalam siklus konsentris sebagaimana skema di atas. Pertama, persuasi dan kesaksian Roh Kudus. Poin pertama ini bersifat subjektif dan eksistensial. Karya Roh dalam diri subjek tidak perlu tergelincir ke dalam subjektivisme dan irasionalitas. Roh menempuh jalan subjektif yang objektif, karena la meneguhkan Kitab Suci, dan memberikan keyakinan yang pasti menyangkut kebenaran. Peneguhan oleh Roh dapat diuji secara intersubjektif. Dalam hal ini, komunitas gerejawi mempunyai peran penting. Lalu, penyingkapan kebenaran Roh tidak melulu mengacu pada sesuatu yang baru, tetapi juga menunjukkan bahwa sesuatu itu benar. Posisi Roh menempati ke- 
dudukan utama, karena hanya Allah yang dapat berbicara bagi Allah.

Kedua, terkait dengan aksi atau perbuatan Allah dalam penciptaan dan sejarah. Dalam mendekati penciptaan dan sejarah, Apologetika Kristen memulai dengan praanggapan ('presupposition', Ramm seorang apologet presupposionalist) yang berbeda dengan para sejarawan. Setiap interpretasi atas sejarah juga tidak terlepas dari semangat zaman yang sedang bergulir atau berlangsung pada masanya. Beberapa perbuatan ilahi dari Allah atas sejarah yang disaksikan oleh Kitab Suci, dan di dalamnya diteguhkan melalui nubuat-nubuat para nabi, mukjizat-mukjizat dan kebangkitan Kristus, perlu dibaca bukan secara modern, melainkan sedekat mungkin dengan maksud teks disampaikan pada saat itu. Melalui pelbagai pengungkapan ilahi itu, yang kemudian berkesinambungan dalam pengalaman Kristen yang meyakini dan mengalami penyingkapan dan perbuatan Allah yang hidup itu, maka fondasi Kristen dalam mendekati sejarah ialah, bukan sekadar laporan masa silam yang dilaporkan berdasarkan kaidah seleksi empiris dan narasi heroik, melainkan sejarah sebagai sejarah keselamatan. Di dalamnya baik penciptaan maupun penebusan berjalan bersama. Semua itu dipersaksikan dan dipersuasikan oleh Roh Kudus melalui peristiwa dan firman. Tanpa kesaksian Roh, sejarah akan berhenti sebagai laporan peristiwa besar yang telah lalu belaka.

Ketiga, visi sinoptik. Ramm menciptakan istilah ini untuk merujuk pada suatu perspektif, visi atau bingkai besar yang saling terintegrasi, koheren, inheren dan komplementer kompleksitas tiap-tiap bagiannya yang membentuk dan memengaruhi setiap subjek dalam mendekati realitas, menafsirkan fakta, mengambil keputusan eksistensial, dan seterusnya. Visi sinoptik dalam iman Kristen mendapat referensi dari kore- lasi antara manusia, kemanusiaan, dunia dan Allah. Menurut penulis, visi sinoptik yang dimaksud Ramm serupa dengan worldview ('pandangan dunia') yang kita kenal hari ini, sekalipun pada masa Ramm term worldview telah lazim digunakan, khususnya di belahan Eropa (mis. Jer. Weltanschauung). Lebih lanjut, Ramm yang terinspirasi oleh Emil Brunner menjelaskan, visi sinoptik adalah pemberian anugerah. Karena visi sinoptik terhubung secara utuh melalui penyingkapan ilahi, yang, sekali lagi, dikerjakan oleh dan melalui Roh Allah. Roh yang sama itu pula yang menolong subjek yang percaya kepada visi sinoptik yang lebih tepat dan objektif. Sekalipun Ramm memberikan catatan, bahwa obsesi sistematisasi atas paradoks dan antinomi di hadapan misteri (seperti salib di hadapan orang Yunani pada masa Rasul Paulus) yang menyenggang perlu diperdamaikan dengan kememadaian koherensi (bukan kesempurnaan) dalam visi sinoptik Kristen (Ramm, 1975, pp. 38-70).

Melalui ulasan garis besar sistem Apologetika di atas, tampak Ramm adalah seorang apologet yang cukup banyak menimbang posisi pneuma. Tiga poin tersebut memaparkan, Roh selalu berperan di dalamnya, sekalipun pada poin pertama secara khusus Roh Allah menempati segmen tersendiri. Ramm juga menyadari, upaya sistematisasi atas perbuatan Allah yang adalah Roh itu, yang sebagiannya merupakan misteri, tidaklah memungkinkan (setidaknya secara betul-betul utuh). Selain itu, didapati pula kejelasan atau klarifikasi melalui paparan Ramm, bahwa Apologetika bukanlah soal metode dan hal-hal praktis lainnya, melainkan soal sistem yang saling terhubung melalui kesaksian dan persuasi Roh Kudus, perbuatan Allah dalam penciptaan dan sejarah, serta visi sinoptik atas realitas. Garis besar Apologetika yang diuraikan oleh Ramm cukup dekat dengan maksud penulis 
menyangkut meta-metode Apologetika, sekalipun tidak tanpa catatan. Walaupun Ramm menyadari posisi Roh yang tak terbatas itu tidak dapat ditampung ke dalam suatu obsesi sistematisasi, namun Ramm tetap melakukan semacam sistematisasi, yang walaupun berhasil, namun terkesan menampilkan kedudukan Roh Allah sebagai terfragmentasi, atau tersegmentasi dalam poin pertama saja. Sekalipun dalam ulasannya menyangkut poin kedua dan ketiga, Ramm menghadirkan kembali Roh di dalamnya. Selain itu, Ramm lebih memusatkan perhatian pada korelasi Apologetika dan iman Kristen pada pokok bahasannya, dengan menambahkan pada bagian selanjutnya soal pendekatan atas bukti-bukti (yang memang merupakan konsentrasi sekaligus titik lemah dari Apologetika di era modern), bukan pada Apologetika dalam kaitan dengan disiplin teologi dan diskursus dengan ranah-ranah lain, yang perlu dijembatani dan dengan menimbang kemungkinan-kemungkinan lebih luas dari sekadar rigiditas keilmuan modern.

Dalam pada itu, dengan menimbang keutamaan pneuma dalam Apologetika, dalam keterhubungan dengan disiplin teologi dan diskursus dengan ranah lain, maka saya mengusulkan meta-metode Apologetika yang dapat diskemakan sebagai berikut.

Gambar 2. Garis Besar Meta-metode Apologetika Kristen

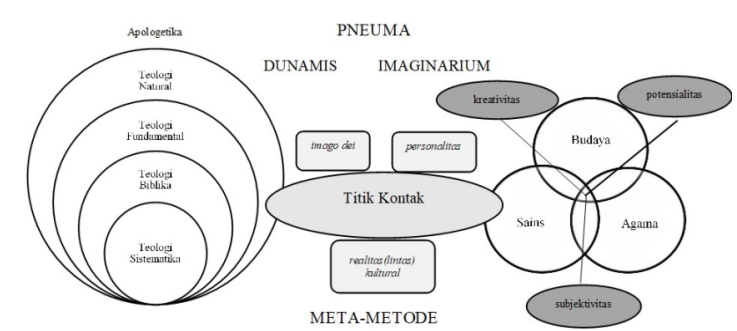

Berdasarkan skema di atas, Apologetika menempati lapisan terluar dari disiplin teologi. Pada lapisan pertama terdapat Teo- logi Sistematika (TS). Dapat dikatakan TS merupakan cabang utama atau inti dari disiplin teologi. TS menjadi semacam sistematisasi atau gagasan yang komprehensif menyangkut tema-tema besar teologis yang muncul dalam Alkitab, seperti Allah Trinitas, manusia, dosa, Kristus, keselamatan, eskatologi, dst. Belakangan muncul disiplin Teologi Konstruktif, yang membuat tema-tema besar itu dapat berdialog cair dengan isu-isu konkret hari ini, baik global maupun regular, atau secara imajinatif (sekaligus mengisi kekurangan pada sebagian besar karya TS yang cenderung rasional semata) dengan gagasan-gagasan teologi pada abad-abad tertentu secara lentur dan dinamis, sembari menimbang praksis bagi masa kini.

Sementara dalam Teologi Biblika (TB) pada lapisan kedua, gagasan-gagasan teologis dalam Alkitab ditinjau dari perspektif penulis tiap-tiap kitab, yang boleh jadi mempunyai variasi gagasan menyangkut ide-ide teologis tersebut, dan tidak dituntut untuk melakukan sistematisasi total menjadi satu ide tunggal. Karena setiap kitab memiliki sistem tersendiri. Pada lapisan ketiga terdapat Teologi Fundamental (TF). Pada umumnya, TF lebih dikenal di kalangan teologi Katolik, walaupun dalam sejarah perkembangannya mendapat pengaruh luas dari teolog-teolog Protestan (lih. O'Collins, 2011, p. 2). Berbeda dari TS dan TB yang merupakan lapisan dalam dari teologi, TF tergolong lapisan luar. TF muncul dalam upaya menjawab pertanyaan-pertanyaan yang timbul dari rahim modernisme. Pertanyaan-pertanyaan itu kemudian dijawab dan dirangkum serta dirumuskan ke dalam beberapa tema besar secara komprehensif oleh TF bagi kepentingan gerejawi (orangorang percaya). Ada pun tema-tema seputar TF termasuk: (1) pewahyuan Allah dalam sejarah Israel dan Yesus Kristus; (2) situasisituasi potensial manusiawi untuk menerima pesan komunikasi dari Allah melalui iman; 
(3) kesaksian yang menghubungkan kita dengan seluruh karya penyelamatan Kristus sehingga menjadikan iman kepada Dia merupakan pilihan mumpuni yang mungkin; (4) penyampaian pengalaman komunikasi diri Allah melalui tradisi dan Kitab Suci; (5) pendirian dan misi gereja Kristen; (6) pertanyaan seputar metode dan pengetahuan teologi, seperti interpretasi teks; (7) menyangkut agama-agama dunia, serta pengaruh kebangkitan Kristus dan kuasa Roh Kudus atasnya (O'Collins, 2011, p. 15). Dalam hal ini TF sedikit berbeda dengan Apologetika, karena Apologetika tidak bermaksud melakukan sistematisasi atas pertanyaan-pertanyaan guna menghasilkan suatu gagasan teologis komprehensif pada lapisan luar tersebut.

Pada lapisan luar keempat, terdapat Teologi Natural (TN). TN merupakan lapisan terluar sekaligus lapisan tertua dengan tradisi teologis membentang sepanjang dua milenium. Alister McGrath merangkumnya dalam enam pendekatan (definisi dan skop) atas TN, yakni: (1) TN sebagai cabang filsafat yang memandang natur tanpa bantuan pewahyuan dapat menyampaikan pesan tentang Allah; (2) TN mengukuhkan keberadaan Allah berbasis pada kompleksitas dan regularitas dunia natural; (3) TN sebagai kecenderungan natural dari akal intelektual yang menghasratkan Allah; (4) TN sebagai perambahan analogi atau resonansi intelektual antara pengalaman manusia atas natur dan Injil; (5) TN menunjukkan upaya kaum naturalis untuk menawarkan pandangan dunia natural dan kajian sains dalam sistem tertutup sebagai kurang memadai, sehingga pendekatan teologis dibutuhkan untuk memberikan interpretasi yang koheren dan komprehensif atas tatanan natural; (6) TN sebagai teologi natural berdasarkan pandangan Kristen atas dunia natural, beranjak dari asumsi-asumsi iman Kristen, yang kontras dengan asumsi kaum naturalis atau sekularis. Enam pendekatan tersebut dapat dibayangkan saling terkoneksi satu sama lain (thick description) tanpa perlu didekati secara otonom-biner (thin description) (McGrath, 2017, pp. 18-23).

Pada lapisan terluar, atau di luar lapisan, merupakan ranah Apologetika. Pertama, sebagai ranah di luar lapisan, hakikat Apologetika memang tidak berpretensi untuk membangun suatu kompendium teologi. Artikulasi Apologetika bersifat cair dan luwes, nonrigid, atau tidak terpaku pada satu lingua teknis partikular. Karena Apologetika hendak merespons pertanyaan-pertanyaan yang jawabannya diperuntukkan kepada orangorang belum percaya sebagai penanya, yang mungkin sekali tidak mengenal artikulasi iman dan teologi Kristen. Kedua, penulis mau menunjukkan, Apologetika merupakan ranah yang melampaui metode dan sistem, atau Apologetika sebagai meta-metode. Ketiga, mengungkapkan bahwa Apologetika tidak muncul tanpa lapisan-lapisan teologi sebelumnya. Justru lapisan-lapisan itu memungkinkan Apologetika ada. Apologetika mengandaikan telah melewati semua lapisan teologi itu, untuk membangun jembatan kepada dunia luar. Dalam arti, Apologetika berangkat dari asumsi-asumsi iman dan teologi Kristen, lalu berupaya untuk membahasakannya dengan bahasa yang mungkin dimengerti oleh dunia luar.

Dengan memahami Apologetika sebagai lapisan terluar atau di luar lapisan, maka perlu dicermati beberapa titik kontak Apologetika kepada dunia luar. Pertama, menyangkut imago dei. Poin pertama ini lebih tepat disebut sebagai alasan bagi adanya kemungkinan titik kontak, atau tentang pertanyaan mengapa titik kontak itu mungkin?; bukan titik kontak an sich. Dalam arti, imago dei merupakan pendasaran teologis atas kemungkinan titik kontak. Menurut McGrath, imago dei merujuk pada pelandasan Apologetika pada doktrin penciptaan 
dan penebusan secara dialektis yang bermuara pada "keretakan relasi dengan Allah dan penerimaan yang tak terpenuhi atas Tuhan di dalam kita" (McGrath, 1998, p. 20). Meminjam istilah Agustinus, McGrath menjelaskan ada memori laten tentang Allah dalam diri manusia, yang memungkinkan titik kontak sebagai titik berangkat Apologetika (1998, p. 21). Imago dei itu juga berjumpa dengan fondasi teologis menyangkut Allah yang mengomunikasikan diri melalui bahasa manusia, yang dalam batas tertentu dapat direspons oleh manusia (McGrath, 1998, pp. 26-41). Roh Allah berperan dalam komunikasi itu, di dalam dan melalui keterbukaan manusia atas alam, diri dan Kitab Suci.

Kedua, menyangkut personalitas. Dalam arti pertama, personalitas mengetengahkan tentang aspek kedirian apologet, sosok yang menyampaikan apologia. Aspek personal ini menyangkut kepribadian, karakter, sikap, perilaku, logat, disposisi tertentu, dst. yang dapat digunakan oleh Roh Allah untuk menanggapi situasi apologetis khusus secara kreatif. Personalitas berbeda dari pendekatan Apologetika yang bertendensi rasional semata. Dalam arti kedua, hal ini menyangkut identitas yang lain. McGrath mengulas beberapa hal tentang identitas dan potensi mereka: (1) rasa ketidakpuasan eksistensial dalam diri manusia; (2) rasionalitas manusia yang terus mencari jawaban atas pertanyaan-pertanyaan ihwal realitas (Allah, dunia, manusia, dst.); (3) tatanan dunia natural yang terus menerbitkan pertanyaan menyangkut muasalnya sampai saat ini oleh para sarjana dan ilmuwan; (4) moralitas manusia, yang secara fundamental terwujud dalam rasa tanggung jawab moral kepada orang lain, atau dorongan kewajiban untuk melakukan kebaikan; (5) rasa keterasingan dan kecemasan eksistensial yang mendorong manusia tiba pada titik reflektif dan disposisi fundamental (hal ini juga terkait dengan philosophia Hei- deggerian yang telah dibahas di atas); (6) kesadaran akan keterbatasan dan kefanaan yang membangkitkan kesadaran akan hakikat yang melampaui itu semua (1998, pp. 51-73).

Ketiga, menyangkut realitas (lintas) kultural. Apologetika dalam konteks Indonesia berhadapan dengan kepelbagaian budaya yang merupakan realitas sehari-hari. Kenyataan pluralitas itu menjadi titik kontak Apologetika yang penting. Setiap budaya mengemban pandangan dunia dan kebiasaan tertentu yang khas. Klaim-klaim inwal metode dan sistem Apologetika, apalagi pendekatan yang lahir dari dunia Barat modern (sebagaimana natalitas Apologetika modern berawal dari pergulatan rasionalisme/naturalisme modern di belahan sana) yang cenderung berwatak monokultural dan membangun sistem total dengan narasi besar, dirasakan sebagai kurang relevan berhadapan dengan realitas multikultural, bahkan multi-subkultural di Indonesia. Dalam hal ini meta-metode Apologetika menyangsikan segenap perangkat metode, sistem, dan (sekadar) langkahlangkah praktis, apalagi yang bersumber dari dan secara jelas merupakan logika instrumental; terlebih-lebih yang lahir dari partikularitas parsial yang terobsesi secara libidis untuk membingkai multiversalitas realitas, konteks, bahkan identitas. Mengenali dan memiliki rasa kepekaan perihal kekayaan kultural itu sangat membantu dalam pendekatan yang sesuai dengan analogi dan narasi kultural, yang merupakan tugas abadi Apologetika yang tidak akan pernah selesai.

Suatu peristiwa kultural yang monumental tercatat dalam Kisah Para Rasul 2, yakni perayaan Pentakosta atau 'Hari Raya Tujuh Minggu' yang lazim dirayakan oleh orang-orang bertradisi Yudaisme pada masa itu, sebagai tanda ucapan syukur atas hasil panen. Orang-orang Yahudi yang tersebar 
atau merantau ke berbagai wilayah lain, tampaknya menjalankan tradisi mudik, dengan kembali ke Yerusalem untuk berpartisipasi dalam perayaan. Mereka yang berdarah Yahudi, maupun keturunan antarras yang masih meneruskan tradisi Yudaisme, telah menyerap budaya tempat mereka hidup di perantauan, bahkan telah berbahasa sesuai dengan lokasi tinggal masing-masing. Mereka mempunyai identitas kultural hibrid: berbudaya Yahudi, sekaligus berbudaya lokal masing-masing, yang terungkap melalui bahasa. Para rasul, beberapa perempuan, ibu dan saudarasaudara Yesus menantikan "janji Bapa". Mereka berkumpul di Yerusalem, di suatu loteng rumah sambil berdoa, sampai pada hari perayaan kultural Yahudi, Pentakosta (Kis. 1:4, 12-14). Janji Bapa yang dipesankan oleh Yesus untuk dinantikan itu adalah Roh Kudus, yang akan memberikan kuasa (dunamis) kepada mereka untuk menjadi saksi Kristus (Kis. 1:8). Beberapa imaji yang muncul dari dunamis ialah dinamo, dinamit dan dinamis. Tiga imaji itu tampak dalam narasi teks Pentakosta (Kis. 2:1-13). Pertama, dinamo. Ketika Roh Kudus memenuhi mereka, mereka "mulai berkata-kata dalam bahasa-bahasa lain, seperti yang diberikan oleh Roh itu kepada mereka untuk mengatakannya" (Kis. 2:4). Dunamis Roh Kudus itu bagaikan dinamo yang mendorong, menggerakkan, dan memicu mereka masingmasing, untuk memulai berkata-kata dalam heteros glóssa.

Kedua, dinamit. Ketika Roh Kudus itu memenuhi mereka, diawali oleh "suatu bunyi seperti tiupan angin keras" (2:2) yang membuat orang banyak yang sedang berkumpul di Yerusalem untuk hari raya Pentakosta itu "berkerumun" ke arah sumber suara (2:6). Bagaikan dinamit yang meledak di tengahtengah kerumunan, demikian daya dari Roh yang menyertai orang-orang percaya itu membuat "[m]ereka semua tercengang- cengang dan heran, lalu berkata: 'Bukankah mereka semua yang berkata-kata itu orang Galilea?"' (2:7).

Ketiga, dinamis. Ketercengangan orang banyak disebabkan oleh heteros glóssa yang keluar dari mulut orang-orang Galilea beraksen kentara itu, telah sampai di telinga mereka semua yang berasal dari berbagai lokasi dengan bahasa (dialektos) berbeda-beda, justru sebagai dialek mereka masing-masing (2:8-11). Realitas Roh Allah yang transkultural diungkapkan dalam fenomena translingual dalam arti radikal. Roh memasuki realitas multikultural secara transkultural, dan membuka jalan bagi khotbah Petrus tentang Yesus Kristus (2:14-40). Khotbah Petrus sekaligus merupakan Apologetika kepada sebagian pihak yang menganggap fenomena itu sebagai kemabukan $(2: 13,15)$. Apologetika meta-metode diinisiasi oleh dunamis Roh, dan sebagai ruang yang dinamis bagi dunamis itu bergerak dalam dan melalui (bahkan melampaui) Apologetika. Lebih jauh, pada Roma 1:20, dunamis muncul dalam imaji dinamika. Dinamika ilahi mempunyai kualitas tidak tercerap oleh indra, atau dalam istilah Immanuel Kant: noumena. Dinamika, atau gerak yang menggerakkan itu, berada dalam ranah noumena. Dunamis Allah yang tidak tampak itu, dapat dimengerti via analogia, yakni karya penciptaan. Semesta alam ini dapat dicerap oleh indera, diteliti dan dipahami serta dibayangkan oleh akal dan imajinasi. Dinamika, gerak murni, yang menggerakkan dan menopang seluruh semesta raya, sebagai yang berkualitas noumena, kemudian pegari (tampak-menampakkan-diri) dalam subjektivitas manusia, melalui dunia ciptaan, sebagai yang berkualitas fenomena. Keniscayaan semesta raya sebagai fenomena ketercerapan indra yang mengarahkan subjektivitas pada kebenaran tentang Allah secara terbatas, disebut oleh Rasul Paulus sebagai anapologétos; tidak 
dapat disangkali. Atau, kita tidak dapat berapologia untuk menyatakan fenomena itu sebagai tidak benar.

Melalui dua teks di atas, Apologetika sebagai meta-metode meluaskan dan meleluasakan dunamis di dalam dan melaluinya. Hal ini mengandung dua makna. Pertama, Apologetika meta-metode berlangsung sebagai "ruang" bagi dunamis pneuma bergerak dinamis. Meta-metode menjadi metode yang melampaui metode, karena Roh yang dinamis itu tidak terengkuh oleh metode, sekaligus dunamis itu bisa saja menggunakan metode. Keluwesan meta-metode terhadap dunamis itu memungkinkan realitas multikultural dimasuki, bahkan diinisiasi dan didorong oleh Roh Allah. Kedua, Apologetika meta-metode berlangsung dalam jalan-jalan analogi. Sebagai lapisan terluar, atau di luar lapisan teologi yang mempunyai lingkungan linguistik khas dan tebal, maka meta-metode bergulir via analogia, yang terbuka kepada sebanyak mungkin lingua yang digunakan oleh audiens atau konteks yang dihadapi. Meta-metode terbuka kepada sebanyak mungkin kemungkinan itu sendiri melalui analogi.

Dalam kaitan itu, dunamis tidak terpisah dari imaginarium. Dalam hal ini, metametode Apologetika terbuka pada kemungkinan lain dari ruang-ruang subjektivitas manusia. Saya meminjam lema imaginarium dari Alister McGrath, yang banyak terinspirasi oleh C.S. Lewis dalam kaitan dengan konsepsi di baliknya. McGrath mengusung imaginarium menyangkut teologi natural, yang berkenaan pula dengan Apologetika. Melalui istilah itu, McGrath mengajak untuk mengimajinasikan ulang realitas natural, yang selama masa modern cenderung didekati via rasionalitas dingin yang dipejali oleh logika dan kata dengan seperangkat teori. Tanpa bermaksud menyingkirkan pendekatan teoretis dan saintifik yang kerap mengangkangi berbagai disiplin intelektual lain,
McGrath menawarkan imaginarium sebagai jalan lain yang lebih utuh dalam mendekati realitas natural. Imaginarium bergerak dalam ruang imajinasi, dengan anggapan Lewisian bahwa subjek mendekati realitas dunia secara lebih koheren dalam disposisi mental berupa gambaran besar alih-alih hanya berdasarkan pada susunan kata. Gagasan teologis tentang semesta ditangkap lebih baik secara intuitif oleh imajinasi manusia.

Dalam teologi Kristen, imaginarium diprakarsai oleh metanoia, suatu transformasi imajinasi dan seluruh keberadaan manusia oleh Roh Allah, sehingga sang subjek dimampukan untuk mendekati realitas dengan lebih jernih, mendalam dan utuh. Imaginarium ditransformasi dalam metanoia melalui iluminasi Roh. Dalam hal ini, imaginarium Kristen hanya dimungkinkan via dunamis pneuma. Melampaui pendasaran subjektif belaka, imaginarium secara umum terdapat pula dalam tiap-tiap masyarakat-sebagaimana dinyatakan oleh Charles Castoriadis dan Charles Taylor-sebagai imajinasi sosial. Imajinasi itu dikonstruksi, dikonstitusi dan dikreasikan oleh masyarakat yang membentuk realitas dunianya dalam keterjalinan dengan realitas natural, serta turut menyumbang makna subjektif bagi tiap-tiap insan sosial di dalamnya. Imaginarium itu —McGrath menyitir Heidegger—berbeda dengan Weltanschauung, atau 'pandangan dunia', sebagai penonton belaka atas dunia, yang kurang menekankan dimensi imajinasi, atau imaji kreatif atas realitas, dalam keterlibatan erat antara subjek/sosialitas dan realitas yang diimajinasikannya. Sebagai kenyataan sosial, gereja juga dibentuk dan didorong oleh suatu visi imajinatif, atau imajinasi ekklesial, sekaligus menginterpretasikan imajinasi itu, serta menawarkannya kepada dunia sekitar; kepada imago dei yang retak, yang dapat menangkap imaginarium itu samar-samar (McGrath, 
2017, pp. 41-61).

Apologetika meta-metode meleluasakan pneuma melalui dunamis dan imaginarium yang memungkinkan pula metanoia, atau transformasi imajinasi. Berhadapan dengan tiga lokus utama, yakni Sains, Budaya dan Agama (SBA), maka Meta-metode Apologetika merembes masuk ke dalamnya, melalui (inter)subjektivitas manusia. Secara terang, peririsan antara ketiganya ialah pada ranah subjektivitas. Insan-insan yang mengkaji atau menghayati SBA itulah-bukan terutama pada polemik di seputar ketiga ranah tersebut-yang menjadi perhatian utama. Subjek-subjek yang mewarisi jejak imago dei itu, mempunyai sekaligus menanggapi kreativitas dan potensialitas, yang terbuka kepada dunamis dan imaginarium. Kreativitas dalam arti, subjektivitas mampu mengambil jarak kreatif dan imajiner dengan SBA yang membentuk/memengaruhinya, melalui daya kreasi, imajinasi, analogi dan seni. Bahkan, daya kreasi, imajinasi, analogi dan seni dapat dimunculkan oleh apologet melalui SBA yang dihayati oleh audiens/ konteks sebagai jalan perjumpaan dengan imaginarium. Potensialitas dalam arti, subjektivitas terbuka pada berbagai kemungkinan potensial dalam hidupnya. Dalam tuturan Heidegger, manusia itu terbentang di antara masa depan dan masa lalu, sebagai suatu kemungkinan. Waktu kehidupan yang dijalani subjek itu merentangkan sekian kemungkinan, yang terbuka pada perubahan. Dalam arti itu, SBA bukanlah determinan permanen, melainkan habitat hasil habituasi subjek, atau yang diterima begitu saja sebagai suatu habitus atau tradisi. Potensialitas subjek itu, yang menerima stimulus dari imaginarium yang ditawarkan oleh apologet/ komunitas ekklesial, dan melalui dunamis pneuma yang mahadinamis, dapat mengalami metanoia. Meta-metode Apologetika menjadi mungkin melalui dunamis dan imaginarium yang melintasi dan meresapi batas-batas SBA hingga menyelusup ke dalam subjektivitas manusia.

\section{KESIMPULAN}

Melampaui pengertian dan pendekatan atas Apologetika yang begitu identik dengan metode, kepraktisan dan sistem rasional tertentu untuk menjawab pertanyaan seputar iman Kristen, paparan di atas telah menunjukkan, Apologetika lebih dari sekadar rumusan standar/latah menyangkut halinwal tersebut. Apologetika meta-metode, sebagaimana beberapa teks dalam Alkitab, menimbang prioritas pneuma, yang tiada dapat dimasukkan ke dalam satu metode, kepraktisan dan sistem tertentu. Dalam pada itu, meta-metode Apologetika menjadi semacam ruang bagi dunamis dan imaginarium yang dapat bergulir secara dinamis dan cair di hadapan realitas multikultural seperti (di) Indonesia. Dengan menimbang tiga lokus besar, yakni Sains, Budaya dan Agama, meta-metode Apologetika menempuh rongga-rongga subjektivitas manusia, sebagai peririsan yang niscaya dari tiga ranah tersebut. Oleh sebab itu, di tengah kebinekaan yang telah menjadi realitas lumrah kita, Apologetika meta-metode meniti jalan dialogis dalam arti seluas-luasnya (baik verbal maupun nonverbal), yang tidak terpaku pada kekakuan sistem dan metode tertentu. Dialog membuka berjuta kemungkinan, kreativitas dan imajinasi, yang melaluinya dunamis dan imaginarium, oleh dinamika Roh Allah yang transkultural, adikreatif, dan mahaimajinatif, memberi arah dan jalan baru nan klasik bagi perkembangan Apologetika yang dinamis, progresif, serta sensitif terhadap realitas multikontekstual. 


\section{DAFTAR RUJUKAN}

Heidegger, M. (1958). What is Philosophy? New York: Twayne Publishers Inc.

Kärkkäinen, Veli-Matti. (2002). Pneumatology: The Holy Spirit in Ecumenical, International, and Contextual Perspective. Grand Rapids: Baker Academic.

McGrath, A. E. (1998). Bridge-building: Effective Christian Apologetics. Leices-ter: IVP. (2017). Re-Imagining Nature: The Promise of a Christian Natural Theology. West Sussex: Wiley Blackwell.
O'Collins, G. (2011). Rethinking Fundamental Theology: Toward a New Fundamental Theology. Oxford: Oxford Univ. Press.

Scott, G. A. (Ed.). (2002). Does Socrates have a Method?: Rethinking the Elenchus in Plato's Dialogues and Beyond. Pennsylvania: Pennsylvania State Univ. Press.

Ramm, B. L. (1975). The God who Makes a Difference: A Christian Appeal to Reason. Waco: Word Books. 